\title{
LIFELONG LEARNING MANAGEMENT SYSTEM IN VIDZEME REGION
}

\author{
Sarma Cakula \\ Kaspars Osis \\ Atis Kapenieks \\ Vidzeme University of Applied Sciences, Latvia
}

\begin{abstract}
In today's rapidly changing environment, lifelong learning is becoming an important part of education system. There is no comprehensive strategy or technological support for lifelong learning in the Latvian regions which could upgrade people's competences and allow them to combine learning with work and family life. It is significant to develop a framework encompassing identification of required competencies, technological support for lifelong learning and make it as part of an ongoing process. The goal of the paper is to create a theoretical framework lifelong learning management technological model and prototype for the Vidzeme region. The focus of the paper is identifying the major steps and elements required to design and incorporate latter mentioned lifelong learning process and particularly adult education perspective supporting technological model in the Vidzeme region. Theoretical framework has been conducted regarding different adult education supporting technological platforms and adult education processing in European Union's regional context. The paper represents the theoretical preconditions for qualitative development of lifelong learning in the region and presents a technological model prototype which would provide the lifelong learning process with ongoing technological support.
\end{abstract}

Keywords: Lifelong learning, knowledge management, technologically supported learning system, regional lifelong learing development technological model.

\section{Introduction}

The change from the industrial age to the information age characterizes nowdays situation. The information age is connected with the production and usage of information, deployment of ad-hoc solutions and being accustomed to use a wide variety of information types for decision-making purposes. The knowledge and skills for quick orientation in a large-scale information flow is of great value. People have experienced such phenomenon as information overload. Accordingly this requires more skills and knowledge to operate them.

A way of obtaining new knowledge and skills already for a while has been seen as an actual aspect of adult and continuing education and it shows no signs of losing its importance. Ritchey developed new directions for adult and 
continuing education (Ritchey, 2008). Currently, it is not possible to be a professional in any field without continuous lifelong learning. The problem which Latvia faces is the fact that many people move abroad in search of job possibilities and the problem for Latvia regions is that many well-educated people choose to work in the capital. Similar situation related with loosing well educated individuals in regions also is observable in other European Union (EU) countries (Juceviciene, 2013, Grady, 2013). In the period of 2007- 2014, depopulation took place in all regions of Latvia but the Vidzeme region occupies the second place after the Latgale region in this respect with a decrease of 12,9\% in the population (VPR, 2015). From one side, people are leaving to other countries for economic reasons; on the other side, young people tend to leave the city for better employment opportunities and a more diverse cultural life.

It is a problem that there is no all-inclusive technological support or roadmap available for adult education in the regions of Latvia that could foster identification and acquisition of required knowledge, skills and serve as uniting element for learning, work and personal time.

There have been other similar projects focusing on regional development (e.g. in South Denmark Region, Stuttgart region, Rhône-Alpes, region of Lombardy, Pori region, East Sweden and Dorset region) and particularly also on adult continuing education and lifelong learning. There has not been a fundamental conception of how lifelong learning is vital for regional development all together (Hansen et al., 2004). In some regions lifelong learning is regarded as a neglected subject and it is pointed out that lifelong learning is both critical to lives of residents and supportive to tackle important economic, social and political tasks in regions (O'Grady, 2013). Based on Interreg IVC analysis especially in EU areas with declining population it is huge problem to maintain high-quality education systems (Galjaard, 2014). Thus there is a need for new and innovative approaches towards adult education and distance learning. The goal of the paper is to create a theoretical framework lifelong learning management technological model and prototype for the Vidzeme region.

This paper is related with a broader research focused on development of lifelong learning strategy framework for Vidzeme region. This broader research encompasses several projects. At this stage of the research this paper reports on results of one particular project and focusses on actual demands based knowledge intensive technological model for lifelong learning development in Vidzeme Region. The paper represents the theoretical preconditions for qualitative development of lifelong learning in the region and presents a technological model which will provide the lifelong learning process with ongoing technological support. 


\section{Conceptual Model if Lifelong learning in Vidzeme region}

The European Commission has put forward seven flagship initiatives to catalyse progress under each priority theme and two of them are focused on education and lifelong learning: "Youth on the move" to enhance the performance of education systems and to facilitate the entry of young people into the labour market; „An agenda for new skills and jobs” to modernise labour markets and empower people by developing their skills throughout their lifecycle with a view to increase labour participation and better match of labour supply and demand, including through labour mobilit (EU, 2015).

\section{Adult education}

Basic notions of adult related learning approaches are identified before to focus on different adult education supporting technological platforms. Based on The Canadian Encyclopedia adult education is regarded as both a field of study and a field of practice (CE, 2013). According to UNESCO, as a field of practice adult education denotes the entire body of organized educational processes, whatever the content, level or method, whether formal or informal, and whether the processes prolong or replace initial education in schools, colleges, universities or apprenticeship systems. Livingstone regards to adult education as adult learning and identifies several basic forms of learning (e.g. further education and informal learning) which are contained by notion of adult education (Livingstone 2012).

Many European countries do not have a clear national strategy for the use of innovative or enhanced learning technologies in adult education and training. The existing legal framework however foresees measures for enhanced ICT and OER use in educational environments; though the vast majority of these measures are addressed to school education (primary and secondary in particular). Some measures have been foreseen for higher education, too, but very few have been foreseen for adult education after formal schooling.

Usage of ICT for support of adult education initiatives has become rather necessary. In last couple decades different adult education supporting technological platforms have been researched and developed. There are several terms used to regard different type of education supporting technological platforms (e.g. learning platform, e-learning platform, e-learning system, learning management system or virtual learning environment) (Ardito, 2004, Holyoke, 2011, Watson, 2007, Ellis, 2009). Some scientists state that e-learning platform is education supporting environment encompassing tools, services and several attributes (Ardito et al., 2004). It is a teaching and learning toolset to 
foster a student's learning experience by involving ICT and Internet solutions in the learning process (Holyoke, 2011). Presence technology is an integral part of wireless networks and is being employed across a wide variety of communication devices, including smartphones, laptop computers, PDAs, television sets, and pagers. Privacy issues are typically addressed by allowing a high degree of user-defined control, allowing people to select conditions in which they are detectable.

There are taken several approaches to come up with technical solutions for e-learning platforms, LMS and for other type of e-learning systems. Several research paths follow the idea of using artificial intelligence (AI) methods and techniques to develop software solutions including e-learning systems supporting applications. Among several such approaches there can be pointed out genetic algorithms (Huang et al., 2006), neural networks (Villaverde et al., 2006), fuzzy logic (Chen, 2007) and software agents based e-learning systems supportive functionality (El-Bakry et al., 2009, Osis et al., 2010, Ivanovic, 2014). There are developed e-learning platforms based on mobile solutions (Elfetouh et al., 2013, Wang et al., 2014). Another adult and continuing education supportive technological solution focuses on already existing skills of learners for learning purposes. Particularly a well-rounded approach is developed by Kapenieks et al. focusing on multi-screen e-learning development entitled "eBig3". This is a technology supported new lifelong learning education paradigm utilizing and combining widely used technologies of Internet, television and mobile phones (Kapenieks et al., 2013, 2014) in a one combined solution.

\section{Knowledge management for lifelong learning}

Knowledge management requires technologies to support the new strategies, processes, methods and techniques to better create, disseminate, share and apply best knowledge, any time and any place. It is a systematic process that focuses on the acquisition, transfer and use of effective, topical knowledge and best practice, thus promoting sustainable operation of an organization.

Different environments can have different influences on learning in order to better structure information and ensure a successful flow of knowledge for learner. Knowledge sharing through participation and social interaction is an important facilitator of knowledge acquisition, and hence of learning. To enable successful knowledge flow, a virtual system must ensure services allowing adults to learn everything they need at any given moment and share their experience in the most effective way if they are willing to do so. Knowledge management (KM) is obviously powerful, for an effective KM initiative across 
the organization, there should be knowledge sharing through social interaction, participation, and engagement in various forms. The notion of knowledge management usually is viewed in the context of an organization and it is defined from several perspectives such as process perspective, organizational perspective, systematic and formal perspective (Jakobsone et al., 2012).

The research conducted and described in this paper is part of a larger research containing several projects. It is regarding developing a technological solution to support a lifelong learning (LLL) process in Vidzeme region and particularly focusing on actual demands based knowledge intensive technological model for LLL development in Vidzeme Region. There has not been a fundamental conception of why LLL is vital for regional development in general (Hansen et al., 2004). In some regions, LLL is regarded to be a neglected subject and it has been pointed out that LLL is both critical to the lives of residents and supportive in tackling important economic, social and political tasks in the regions (O Grady, 2013). In this regard, it is important to create an overall strategy for LLL which would incorporate learning as part of an ongoing lifelong process. Besides the official legislative documents which focus on government actions, to improve the take up of adult learning, a small number of recent country reports and research studies reflecting the current situation and focusing on the role of ICT and OER in adult learning, and on developing an innovative learning environments includes the following: pedagogic practices promoted by distance learning educational material on adult education (Christidou et al., 2012); factors influencing adult distance teaching and learning processes (Gravani et al.2011, Hatzinikita et al. 2011).

\section{Conceptual lifelong learning management technological model}

Fig.1 describes the conceptual model of lifelong learning focusing to Vidzeme region is based on European and Latvian strategies including specific of Vidzeme region (Osis et al., 2015). Several best practices in north countries, for example Finland experience, have been analysed (FRDS, 2010). Adult education stakeholders' inclusive technological model equips adult education process with ongoing technological support and sources of actual knowledge and management information. Local stakeholders including local governments, companies and individuals are used as the source data providers for adult education needs requirements for a set period of time. There is used a specific approach to acquire demanded skills and competences information - demands acquisition system (DAS) to perform required competences data acquisition from involved parties. Local governments set clear demands for adult education 
Sarma Cakula, Kaspars Osis, Atis Kapenieks. Lifelong Learning Management System in Vidzeme Region

service providers for a set period of time based on acquired list of required competences.

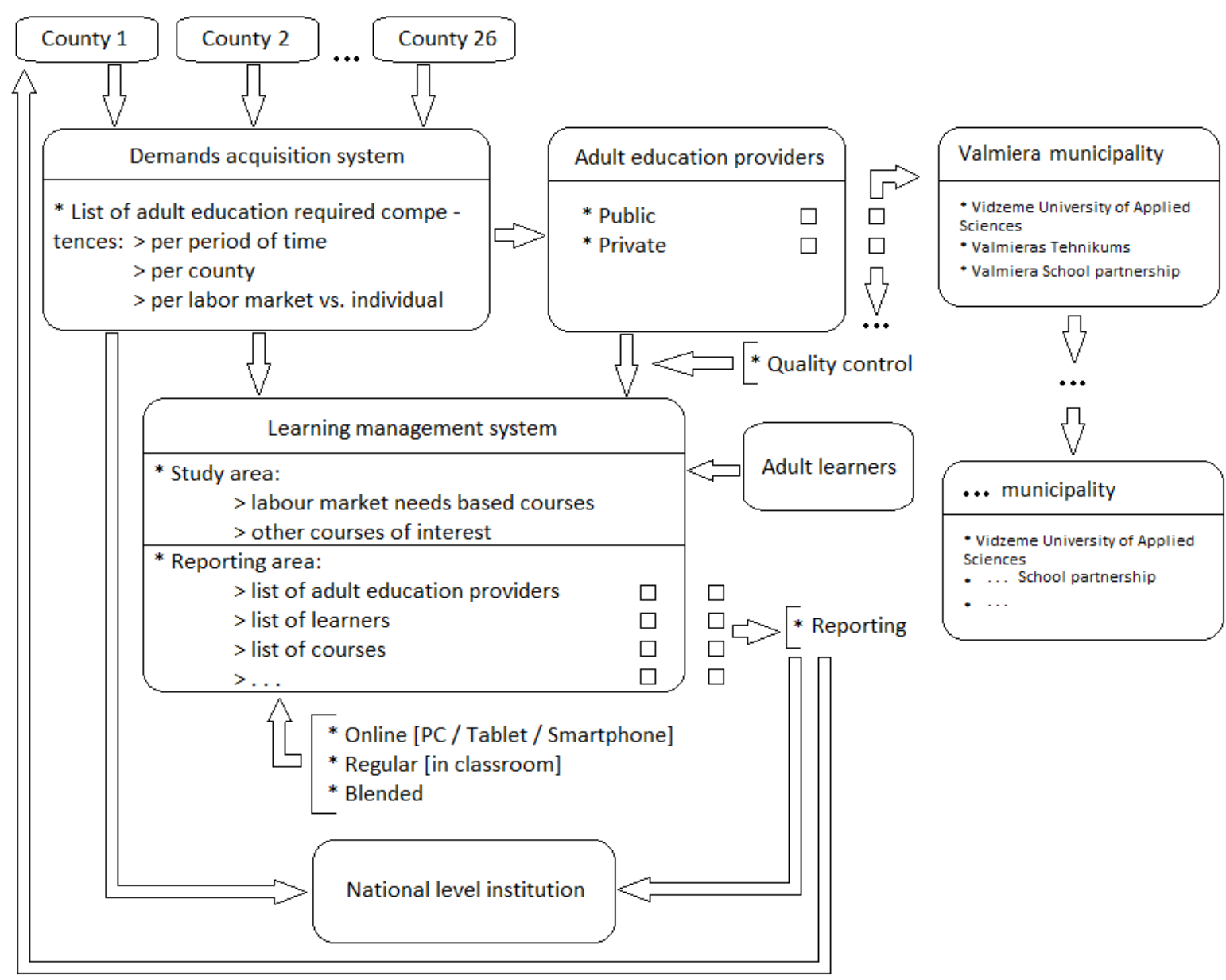

Figure 1 Lifelong learning management technological model for adult education development in Vidzeme Region (updated from Osis et.al., 2015).

It is especially so in case of competences demanded by labour market as Vidzeme region can forward this information to national government which in turn may consider to provide a financial support for running accordant adult education courses. By performing latter mentioned steps and combining found legislative constraints and LMS platform available functionality options there has been designed a required knowledge and competencies identifying and fostering technological model to serve as a roadmap for adult education stakeholders in the Vidzeme region. 


\section{Technological model prototype}

Online learning systems are vastly used for collaborative learning which complements multi-person learning styles, and independent adults have also found online courses to be well-suited to their needs. The system includes all teaching providers in a single place and provides information on all activities in the system. There is also a possibility to request special courses, knowledge and skills from the relevant enterprise or municipality management. As a result, a list of skills, knowledge and competences and functionality options which should be acquired in adult education, defining and fostering the technological model which serves as a roadmap for adult education stakeholders in the Vidzeme region has been drawn.

With technologies constantly evolving, authors are debating another relationship, and that is between education and technology, as adults are getting used to new technologies and expect more flexible learning schemes. Optimal results cannot be reached by quantitative actions alone as long as the current processes and procedures of informatization are shape-shifting while sticking to the same old contents. Basic technological model prototype is focused for using on computer (Fig.2).

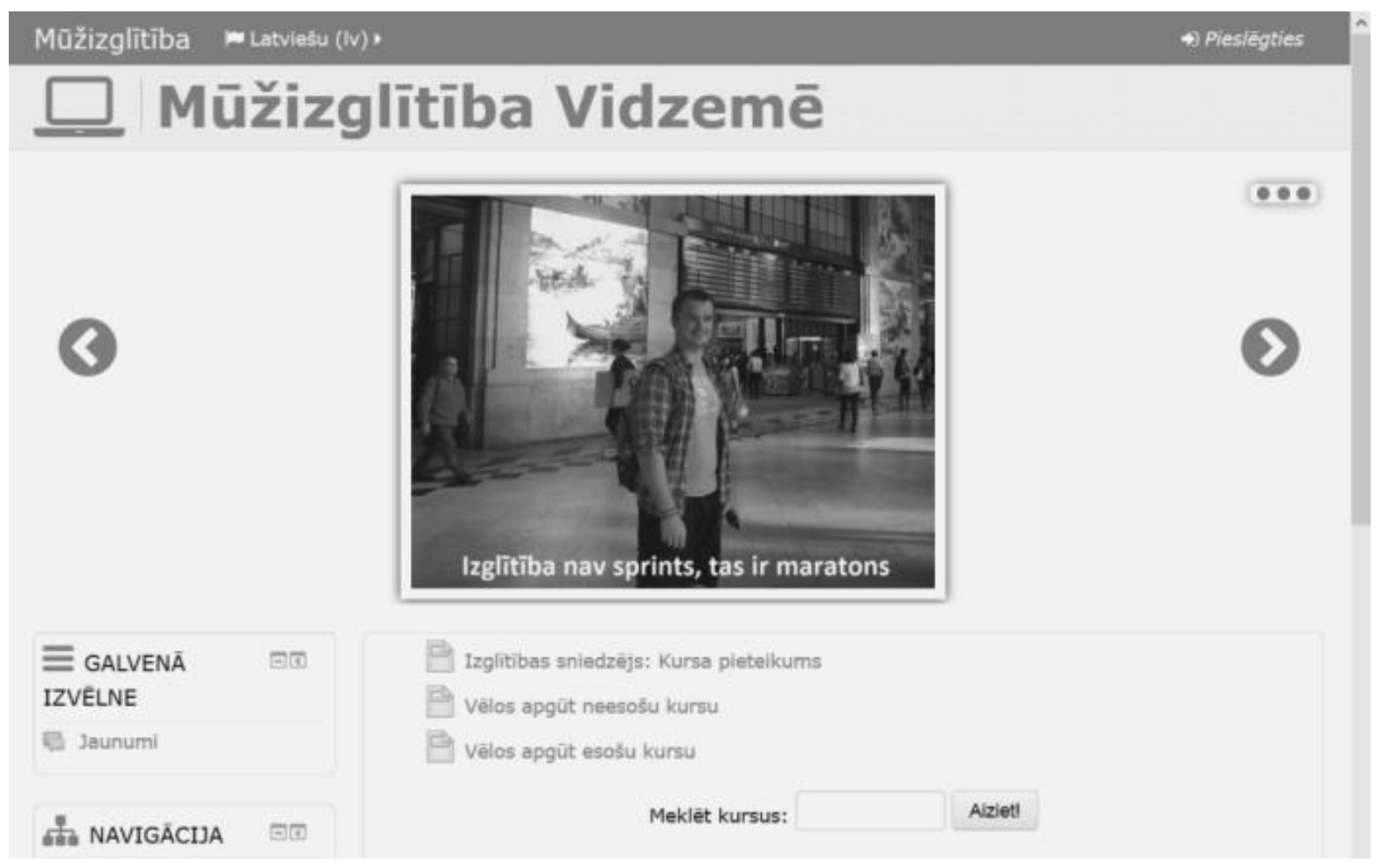

Figure 2 Prototype starting screenshot 
Sarma Cakula, Kaspars Osis, Atis Kapenieks. Lifelong Learning Management System in Vidzeme Region

Prototype includes online communication system managed by local government. Technological model prototype is tested also on different devices such as tablet, smart phone and media player.

\section{Conslusion}

Adult education supported by the technological model combines several areas of the adult education process in the Vidzeme region: the involvement of different types of stakeholders in the development process, competences and skills, demands and the acquisition system, public and private adult education providers and the study process, several reporting options and statistics. Such a technological and strategic framework helps to plan and to perform educational activities, and to evaluate the obtained results of the Vidzeme region adult education process in a longer period of time.

The development of the technological model and framework supporting adult education and the LLL strategy in the Vidzeme region offers a new, more efficient approach to the management of the next generation technologically enhanced lifelong learning process.

Paper describes developed adult education supporting technological model as a working prototype in Vidzeme region. Prototype involves developing the demands acquisition and the quality control mechanism, and accordingly to configure chosen LMS platform to support both study process and extended reporting process.

The next step is to develop lifelong learning strategy in Vidzeme region based on strategy framework and technological solution.

\section{References}

Ardito, C. (2004). Usability of E-Learning Tools. Proceedings of the working conference on Advanced visual interfaces. AVI'04, 80-84.

Chen, Y.H. (2007). Use Feedback and Fuzzy Self-Organizing Map to improve adaptive elearning model. C. Montgomerie \& J. Seale (Eds.), Proceedings of EdMedia: World Conference on Educational Media and Technology. Association for the Advancement of Computing in Education (AACE), 3474-3480.

Christidou, V., Hatzinikita ,V., Gravani, M. (2012). Distance Learning Material for Adult Education: The Case of the Open University of Cyprus. Ubiquitous Learning, Vol. 4(2), 33-46.

El-Bakry, H. M., Mastorakis, N. (2009). Advanced Technology for E-Learning Development. Recent Advances in applied mathematics and computational and information sciences. Vol.II, 501-522.

Elfetouh, A. A. S, El-Bakry, H. M. (2013).A Novel Adaptive Mobile E-Learning Model. International Journal of Computer Applications, Vol. 63(14),12-25. 
Ellis, R. K. (2009). Field Guide to Learning Management Systems. American Society for Training \& Development (ASTD). Learning circuits, ASTD Inc.

Europe 2020. (2015). A European strategy for smart, sustainable and inclusive growth. Downloaded from http://ec.europa.eu/eu2020/pdf/COMPLET\%20EN\%20BARROSO $\% 20 \% 20 \% 20007 \% 20-\% 20$ Europe $\% 202020 \% 20-\% 20$ EN\%20version.pdf

Finland's Regional Development Strategy 2020. (2010). Downloaded from https://www.tem.fi/files/27807/TEM_53_2010_netti.pdf

Galjaard, R.(2014). Demographic change. Interreg IVC analysis report. Downloaded from http://www.interreg4c.eu/fileadmin/User_Upload/PDFs/CAPITALISATION/Report/De mographic_change.pdf

Gravani, M., Hatzinikita, V., Zarifis, G. (2011). The case of the Open University. The International Journal of Learnin., Vol.18 (5), 307-320.

Hansen, H., Multisilta, T., Kuusisto, A. (2004). A holistic and strategic approach to support and promote Lifelong Learning, networking activities and regional learning. An EU project under the R3L initiative. Van Weert T. J, Kendall M. eds., Lifelong Learning in the Digital Age, Springer-Verlag New York Inc; Vol. 137, pp.89-98.

Hatzinikita, V., Katsis, A., Petrogiannis, K. (2011). Hellenic Open University student views on Supplementary Digitized Educational Material, Open Education. The Journal for Open and Distance Education and Educational Technology. Vol 7 (2), 5-19.

Holyoke, M. (2011). Virtual learning environment (VLE) or managed learning environment (MLE). WhatIs.com. Downloaded from http://whatis.techtarget.com/definition/virtuallearning-environment-VLE-or-managed-learning-environment-MLE

Huang, M., Huang, H., Chen, M. (2006). Constructing a personalized e-learning system based on genetic algorithm and case-based reasoning approach. Expert Systems with Applications. Elsevier.

Ivanovic, M. L. C. (2014). Jain, E-learning paradigms and applications: Agent-based approach. Springer-Verlag Berlin Heidelberg.

Jakobsone, A., Cakula, S. (2012). Online Experience Based Support System for Small Business Development. Proceedings of the 8th WSEAS International Conference on Educational Technologies (EDUTE'12). Porto.

Juceviciene, P. (2013). Kaunas stimulus paper. Pascal international exchanges. Available at: http://pie.pascalobservatory.org/pascalnow/ blogentry/pie/kaunus-stimulus-paper.

Kapenieks et al. (2013). "eBig3": a new triple screen approach for the next generation of lifelong learning. Recent Advances in Computer Science 2013. Greece, Rhodes Island, 306-310.

Kapenieks, et al. (2014). Piloting the eBig3 - a triple-screen e-learning approach. 6th International Conference on Computer Supported Education.CSEDU 2014, 325-329.

Livingstone, D. W. (2012). Probing the icebergs of adult learning: Comparative findings and implications of the 1998, 2004, and 2010 Canadian surveys of formal and informal learning practices. The Canadian Journal for the Study of Adult Education, Vol. 25(1), 47-71.

O'Grady, A. (2013). Lifelong learning in the UK. An introductory guide for education studies. Adult and community learning: rural lifelong learning. Routledge, 36.

Osis, K., Cakula, S., Kapenieks, A., Zarifis, G. (2015). Lifelong Learning Strategy Framework for the Vidzeme Region. Procedia Computer Science. Elsevier. Vol. 77, 104-112. 
Sarma Cakula, Kaspars Osis, Atis Kapenieks. Lifelong Learning Management System in Vidzeme Region

Osis, K., Grundspenkis, J. (2010). Agent and Mobile Technologies and Their Usage in Development of Learning Environment Supportive System. 3rd WSEAS International Conference on Visualization, Imaging and Simulation (VIS'10). University of Algarve, Faro, Portugal, 58-63.

Ritchey, J. A. (2008). Adult Education in the Rural Context: People, Place, and Change. New Directions for Adult and Continuing Education, Wiley, Vol.117.

The Canadian Encyclopedia, 2013. Available at: http://thecanadian encyclopedia.com

Vidzemes plānošanas reg̣iona pašreizējās situācijas analīze. (2015). Downloaded from http://www.vidzeme.lv/upload/lv/Attistibas_planosana/Pazinojumi/IAS_AP_Pasreizeja _situacija_30032015.pdf

Villaverde, J. E., Godoy, D., Amandi, A. (2006). Learning Styles' Recognition in E-Learning Environments with Feed-Forward Neural Networks. Journal of Computer Assisted Learning, Vol.22, 197-206.

Wang, G. X., Gao, Y. L. (2014). The design and implementation of mobile learning platform based on WLAN, in Liu, Sung \& Yao (Eds.) Computer, intelligent computing and education technology. Taylor \& Francis Group, London, 361-365.

Watson, W. R. (2007). An Argument for Clarity: What are Learning Management Systems, What are They Not, and What Should They Become? TechTrends. Vol 51(2), 28-34. 